WARSZTATY Z GEOGRAFII TURYZMU

ISBN 978-83-7525-925-4 $\quad$ s. $21-35$

http://dx.doi.org/10.18778/7525-925-4.03

Barbara PISARSKA

Akademia Finansów i Biznesu Vistula, Warszawa

\title{
W DRODZE KU UNIWERSALNOŚCI KLASYFIKACJI FORM REKREACJI, W TYM TURYSTYKI
}

\section{Wprowadzenie}

Celem autorki pracy jest uporządkowanie kryteriów podziału rekreacji, w tym turystyki, oraz prezentacja autorskich koncepcji klasyfikacji zajęć rekreacyjnych, motywów i form turystyki. Poruszane zagadnienia są trudne ze względu na immanentną cechę, zwłaszcza turystyki, jaką jest jej duża zmienność w czasie i w przestrzeni. Może dlatego jej klasyfikowanie pozostawiono żywiołowemu rozwojowi, a nie powinno tak być, ponieważ celem nauki jest dogłębne studiowanie problemów szczególnie złożonych. Jak podkreślają H. BORNE, A. DOLIŃSKI (1988) - podziały ruchu turystycznego są istotne nie tylko do celów naukowych czy statystycznych. Mają one bardzo ważne znaczenie ekonomiczne i organizacyjne, głównie w związku z obsługą turystów. Warto $\mathrm{w}$ tym miejscu przytoczyć definicje turysty, ruchu turystycznego, turystyki i rekreacji, które najbardziej odpowiadają autorce ze względu na przedmiotowy temat.

Według definicji ustalonej na konferencji ONZ w 1963 r. (WARSZYŃSKA, JACKOWSKI 1979), turysta to każda osoba przybywająca do miejsca, niebędą- 
cego miejscem jej stałego zamieszkania, w jakimkolwiek celu, z wyjątkiem wykonywania odpłatnie zawodu. Definicja ta obejmuje:

1) turystów, tzn. odwiedzających, którzy przebywają w danym miejscu co najmniej 24 godziny i których cel podróży można ująć w następujące grupy:

a) wykorzystanie wolnego czasu: rozrywka, wakacje, zdrowie, studia, religia i sporty;

b) interesy, sprawy rodzinne, misje, zjazdy;

2) wycieczkowiczów, tzn. odwiedzających czasowo, którzy przebywają w odwiedzanym miejscu krócej niż 24 godziny.

Współcześnie, zgodnie z WTO (Terminologia... 1995), pojmowanie pojęcia „turysta" jest podobne, ale zakres celów turystycznych uległ znacznemu poszerzeniu (sześć rozbudowanych grup, w tym trzecia - dotycząca spraw zawodowych). Dokładniej na ten temat piszą W.W. GAWORECKI (1994) i A. KOWALCZYK (2001).

Na podstawie przeglądu wielu definicji autorka określa ruch turystyczny jako zjawisko społeczne, którego istotą jest zmiana miejsca pobytu, a podmiotem - człowiek, który ma możliwość wyboru odwiedzanych miejsc, sposobu organizacji wyjazdu i formy turystyki - w zależności od motywów, upodobań, predyspozycji psychofizycznych oraz od warunków socjalnych. Poprzez zamieszczone poniżej uporządkowane kryteria podziału ruchu turystycznego ukazana jest wielka złożoność tego zjawiska.

Jedną z najbardziej uniwersalnych i - w związku z tym - znanych definicji turystyki jest definicja K. PRZECŁAWSKIEGO z 1973 r., według której turystyka to całokształt zjawisk ruchliwości przestrzennej, związanych z dobrowolną czasową zmianą miejsca pobytu, rytmu i środowiska życia oraz z wejściem w styczność osobistą ze środowiskiem odwiedzanym - przyrodniczym, kulturowym bądź społecznym (PrZECŁAWSKI 1979, 1994). Autorka niniejszej pracy uważa, tak jak J. WARSZYŃSKA i A. JACKOWSKI (1979), że termin „turystyka” jest węższy niż pojęcia „rekreacja” czy - po polsku - „wypoczynek", które oznaczają wszelkie czynności podejmowane dla regeneracji sił.

Według T. WOLAŃSKIEJ (1997) - rekreacja (z łac. recreare - uzdrawiać, wzmacniać) to różnego rodzaju zajęcia podejmowane w czasie wolnym, dobrowolnie, dla przyjemności, autoekspresji własnej osobowości, odnowy i pomnażania sił psychofizycznych. O uznaniu zajęć za rekreacyjne decyduje kontekst psychospołeczny, a więc to, czy są to zajęcia dobrowolne, czy spra- 
wiają przyjemność, czy spełniają oczekiwania i zainteresowania, jakie są motywy podejmowania danej czynności, czy wpływają na osobowość w sposób pozytywny, rozwijający. Rekreacja to określony sposób zagospodarowania czasu wolnego.

\section{O kryteriach podziału rekreacji oraz jej klasyfikacjach}

Autorkę niniejszej pracy zawsze interesowały zagadnienia teoretyczne, tzn. definiowanie pojęć, kryteria i klasyfikacje zjawisk związanych z rekreacją $\mathrm{w}$ tym $\mathrm{z}$ turystyką. Na podstawie przeglądu literatury przedmiotu wiadomo, że na tym polu panuje zbyt duża dowolność; niektórzy nie sięgają do wcześniejszych opracowań i nie stosują w pełni reguł metodologicznych. Nikogo rozsądnego nie trzeba przekonywać, że trudno dotrzeć do wszystkich prac dotykających jakiegoś zagadnienia. Niewykluczone, że różne osoby niemal równocześnie mogą wymyślić określone zaszeregowania. Taka ewentualność może dotyczyć bardzo dużego podobieństwa (x) sformułowania zasadniczych kryteriów podziału rekreacji w pracach M. ĎURIČKA, K. OBODYŃSKIEGO (2006 - s. 18) i B. PISARSKIEJ (2006), która upowszechniła je wśród pewnej grupy studentów już wiosną 2004 r. W obu pracach wzorowano się na podejściu Z. SKÓRZYŃSKIEGO (1961). Poza podanymi poniżej pierwszymi dwoma - pozostałe kryteria zostały wymienione $\mathrm{w}$ pracach S. ToCZEK-WERNER (2005), B. PISARSKIEJ (2006) oraz M. NAPIERAŁY i R. MuSZKIETY (2011):

Wykaz kryteriów podziału rekreacji według B. Pisarskiej:

1) zaangażowanie uczestnika (x): rekreacja aktywna (czynna) i pasywna (bierna). B. PISARSKA (2006) wzięła pod uwagę nie tylko obiektywną ocenę aktywności ruchowej, ale również obiektywno-subiektywną ocenę zaangażowania umysłowo-emocjonalnego (pozycja nadawcy albo odbiorcy pewnych treści);

2) miejsce realizacji:

a) w miejscu stałego zamieszkania czy poza nim? (x)

b) w domu czy poza domem?

c) "pod dachem" czy w plenerze, w tym na boisku? (x)

3) wiek (rekreacja dzieci, młodzieży, dorosłych, emerytów); 
4) zainteresowania (bardzo istotne $\mathrm{w}$ poniżej przytoczonej klasyfikacji autorki);

5) pora roku (zajęcia letnie, zimowe, całoroczne);

6) czas realizacji (na co dzień, w święta, w weekendy, podczas wakacji i urlopu);

7) częstotliwość (okazjonalnie, systematycznie, notorycznie - treningi);

8) wielkość grupy (indywidualnie, w parze, w małej grupie, w drużynie);

9) stopień organizacji (spontaniczne, zorganizowane);

10) zależność techniczna: rekreacja bez sprzętu, rekreacja ze sprzętem (jest to bardzo ważne kryterium, ponieważ zabieganie o dostęp do sprzętu (wypożyczenie) zabiera czas i wiąże się, podobnie jak zakup sprzętu - z kosztami, które trzeba przeznaczyć też na jego konserwację czy naprawy; poza tym należy zainwestować czas na naukę bezpiecznego korzystania ze sprzętu, np. roweru, nart, rakiety tenisowej, żaglówki. Rekreacja, w tym turystyka bez sprzętu jest znacznie łatwiej dostępna dla ogółu ludzi.

S. TOCZEK-WERNER (2005) w odniesieniu do rekreacji ruchowej uwzględniła jeszcze dwa kryteria: intensywności wysiłku oraz stopnia trudności. Przytoczyła ona - podobnie jak M. ĎURIČEK, K. OBODYŃSKI (2006) - podział rekreacji fizycznej na dziewięć dyscyplin; turystyka znalazła się w ostatniej grupie zbierającej „inne” dyscypliny. Ciekawą klasyfikację zaproponował w latach 70. minionego stulecia - R. Wroczyński; poza turystyką obejmowała ona zabawy i gry ruchowe (sport), uczestnictwo w imprezach artystycznych, korzystanie ze środków masowego przekazu, inne formy aktywności intelektualnej, zajęcia techniczne, aktywność społeczną i towarzyską oraz inne formy aktywności (za: NAPIERAŁA, MUSZKIETA 2011). Najbardziej ogólna jest - pochodząca z tego samego okresu - klasyfikacja Czajkowskiego, który wyróżnił: rekreację fizyczną, twórczą kulturalno-rozrywkową oraz rekreację przez działalność społeczną (jw.). Trudnym zagadnieniem klasyfikacji rekreacji zajmowali się też M. DEMEL, W. HUMEN (1970), A. KAMIŃSKI (1972), Z. Skórzyński (1961) (za: PISARSKA 2006; NAPIERAŁA, MUSZKIETA 2011).

Klasyfikacja zajęć rekreacyjnych według B. Pisarskiej

I zajęcia bierne (ruchowo; pozycja odbiorcy) w domu:

1) odbiór aktualności z mediów (radio, telewizja, prasa, Internet);

2) odbiór innej oferty (np. kulturalnej) z mediów (jw.); 
3) odbiór treści z odtwarzaczy (np. magnetofon, video, rzutnik, komputer);

4) czytanie książek i czasopism;

5) inne.

II zajęcia bierne (ruchowo; pozycja odbiorcy) poza domem:

1) wyjścia na koncerty muzyczne i spektakle teatralne (opera, rewia, festiwal...);

2) wyjścia do kina i na projekcje filmów (np. w klubie);

3) wyjścia do muzeów, galerii (kontakt ze sztuką plastyczną);

4) wyjścia do czytelni (szkolnych, osiedlowych, naukowych, innych);

5) wyjścia na spotkania towarzyskie (do kawiarni, klubów, do znajomych);

6) wyjścia na zawody sportowe (kibicowanie);

7) wyjścia do świątyń i innych miejsc kultu religijnego;

8) zwiedzanie sklepów, realizacja niekoniecznych zakupów;

9) inne zajęcia, np. leżakowanie, plażowanie;

III zajęcia aktywne (ruchowo, ćwiczenie umiejętności, pozycja nadawcy) w domu:

1) przyjemnościowe wykonywanie zajęć domowych - dbanie o dzieci, rośliny i zwierzęta domowe, „kucharzenie”, porządkowanie (np. książek, fotoalbumów);

2) ćwiczenia gimnastyczne (np. joga), aerobic, taniec;

3) gry i zabawy towarzyskie (w tym z dziećmi) np. karty, warcaby, szachy;

4) gra na instrumencie muzycznym, malowanie, rzeźbienie, fotografia kameralna;

5) pisanie wierszy, dzienników, pamiętników, listów;

6) tkanie, haftowanie, szydełkowanie, dzierganie na drutach, szycie i inne robótki ręczne oraz majsterkowanie i modelarstwo;

7) kolekcjonerstwo przedmiotów użytecznych duchowo (pamiątki rodzinne, patriotyczne) i materialnie;

8) inne.

IV zajęcia aktywne (ruchowo, ćwiczenie umiejętności, pozycja nadawcy) poza domem:

1) przyjemnościowa praca w ogródku przydomowym, na działce;

2) zajęcia sportowe bez sprzętu: biegi, skoki, gimnastyka, pływanie...; 
a) w terenie (ogródek, działka, park, las, boisko, stadion, zbiorniki wodne: naturalne i sztuczne): + spacery, marsze, zbieranie runa leśnego...;

b) pod dachem (sale i hale sportowe, baseny): ...;

3) zajęcia sportowe ze sprzętem: lekkoatletyka, tenis, rolki, hippika, łyżwy...;

a) w terenie: + sanki, narty, rower, paralotnia, kajak, łódź...;

b) pod dachem: + ćwiczenia na siłowni, kręgle...;

4) zespołowy sport amatorski (treningi w stałych grupach): piłka ręczna, siatkówka, koszykówka, hokej na lodzie...;

a) w terenie: + piłka nożna, hokej na trawie...;

b) pod dachem: ...;

5) tańczenie (przyjęcia o takim charakterze, dyskoteki, dansingi);

6) amatorskie zajęcia i występy artystyczne: muzyczne, taneczne, teatralne, plastyczne;

7) spotkania w kołach poznawczych, w tym we wspólnotach religijnych;

8) działalność społeczna: duchowo-etyczna, charytatywna, obywatelska, dziennikarska, proekologiczna, krajoznawczo-turystyczna, sportowa;

9) uprawianie form turystyki bez specjalistycznego sprzętu (turystyka piesza, wycieczki krajoznawcze...);

10) uprawianie form turystyki ze środkiem transportu lub specjalistycznym sprzętem (turystyka rowerowa, kajakowa, żeglarska, narciarska...);

11) inne.

Klasyfikacja ta zawiera cztery główne grupy zajęć z 33 szczegółowymi, których liczba w klasyfikacjach GUS wynosiła: w 1969 r. - 46, w 1976 r. - 49, w 1984 r. - 53, a w 1999 r. - 175(!). Współcześnie mało kto przystępując do badań nad wykorzystaniem czasu wolnego uzasadnia zaproponowane respondentom kafeterie; ich mnogość, przypadkowość i różnorodność prowadzi do nikąd. Warto więc rozważyć upowszechnienie wyżej przedstawionej. 


\section{O kryteriach podziału turystyki i jej klasyfikacjach}

Autorzy piszący o podziałach turystyki rozpoczynali od przytoczenia ich kryteriów. Tej ze wszech miar uzasadnionej tradycji stanie się zadość także w przedmiotowym opracowaniu. Jego autorka na podstawie chronologicznego przeglądu literatury oraz własnych doświadczeń w zakresie zagadnień metodologicznych dotyczących turystyki, przedstawia poniżej wykaz kryteriów klasyfikacji turystyki, istotnych z punktu widzenia geografii turyzmu.

I Kryteria opisujące podmiot(y) turystyki, czyli jej uczestnika(ów):

1) struktura demograficzna - turystyka dzieci, młodzieży, dorosłych, emerytów;

2) struktura społeczno-zawodowa - turystyka mieszkańców miast, wsi, grup zawodowych;

3) struktura ekonomiczna - turystyka socjalna, ludzi średniozamożnych, ludzi bogatych;

4) $\operatorname{motyw}=$ cel wyjazdu - zdrowotny, poznawczy (poniżej);

5) styl uprawiania turystyki - masowa, alternatywna, w tym ekoturystyka.

II Kryteria opisujące wyjazd turystyczny:

1) okres (pora) wyjazdu - turystyka letnia, zimowa, posezonowa, świąteczna, weekendowa;

2) czas trwania wyjazdu - turystyka krótko-, średnio- i długoterminowa;

3) zasięg przestrzenny wyjazdu - turystyka lokalna, regionalna, krajowa, zagraniczna;

4) dominujący kompleks walorów - turystyka nadmorska, nadwodna, górska, uzdrowiskowa;

5) wielkość grupy - turystyka samotnicza, grupowa (w tym rodzinna), zbiorowa;

6) charakter organizacyjny - turystyka indywidualna, organizowana (biuro, zakład pracy, szkoła);

7) przebieg wyjazdu - turystyka pobytowa, wędrowna;

8) rodzaj środka transportu - turystyka samochodowa, lotnicza, promowa...;

9) rodzaj bazy noclegowej - turystyka hotelowa, campingowa, agroturystyka; 
10) skala oddziaływania na środowisko geograficzne: turystyka masowa, ekoturystyka.

Przez długi okres początków rozwoju wiedzy o turystyce w Polsce uwzględniano kryteria, które przytoczyli J. WARSZYŃSKA, A. JACKOWSKI (1979), H. BORNE, A. DOLIŃSKI (1988). Brano więc wówczas pod uwagę ogólnie podmioty turystyki, wyodrębniając różne kategorie demograficzno-społeczne turystów. Poza tym uwypuklono czas trwania podróży, okres wyjazdu, wielkość grupy, stopień organizacji, miejsce docelowe wyjazdu, środek lokomocji oraz sposób zakwaterowania i motyw wyjazdu.

Najbardziej generalnie określił kryteria podziału turystyki S. WODEJKO (1997): pierwsza ich grupa opisuje podmioty turystyki, a druga grupa opisuje podróż. Do tej ostatniej włączył kryterium motywu, które według większości autorów wiąże się zdecydowanie z uczestnikami turystyki. Uzupełniony podział S. WODEJKI (1997) w sposób tabelaryczny ujęły A. DOŁOWY, A. LEWANDOWSKA, B. MEYER (2006).

J. WARSZYŃSKA (1999a, b) zaproponowała nowe nazwy dla wcześniej już przez siebie wyróżnionych kryteriów, np.: przynależność uczestników do grupy społecznej, środowisko, w którym realizowana jest turystyka, zasięg przestrzenny wyjazdu, zaangażowanie profesjonalnych organizatorów turystyki, używany sprzęt turystyczny; na taki podział kryteriów turystyki powołał się M. MIKA (2008).

W. KAPROWSKI $(1999,2004)$ wymienił w swym podręczniku tylko pięć kryteriów: dominujący motyw wyjazdu, czas trwania, zasięg geograficzny wyjazdów, stopień organizacji ruchu turystycznego oraz środki transportu.

K. PRZECŁAWSKI (2004), zapewne w celu uproszczenia zagadnienia kryteriów, ujął je w 12 pytań. Nowymi w stosunku do wymienionych kryteriów były: sposób uprawiania turystyki (kwalifikowany czy niekwalifikowany), charakter przebiegu wyjazdu (pobytowy czy wędrowny) oraz kierunek migracji. Na znaczenie kosztów podróży zwrócił uwagę C. MARCINKIEWICZ (2005). S. TOCZEK-WERNER (2005) wymieniła osiem kryteriów, wśród których nowe dotyczyło dominującego kompleksu walorów kojarzonego z określoną strefą krajobrazową albo generalnie $\mathrm{z}$ uzdrowiskami.

Novum u M. MiKI (2008) polegało na tym, że wskazał on na kryterium cech popytu turystycznego, na podstawie którego dzieli turystykę na komercyjną i niszową (specjalnych zainteresowań). Najistotniejsze z punktu widzenia geografii turyzmu było jednak uwzględnienie przez niego kryterium 
skali oddziaływania turystyki na środowisko przyrodnicze i społeczno-ekonomiczne, z którego wynika podział na turystykę masową i alternatywną w stosunku do niej. Autorka niniejszego opracowania uznaje, że to kryterium ma równocześnie związek z preferowanym stylem uprawiania turystyki przez konkretne osoby i dlatego umieściła je w obu grupach kryteriów (opisujących podmiot i podróż przez niego realizowaną).

W.W. GAWORECKI (2010) jako ekonomista skupił się na kryteriach ważnych dla swojej dyscypliny; wyodrębnił więc kryterium wpływu na bilans płatniczy, na podstawie którego dzieli turystykę zagraniczną na przyjazdową i wyjazdową. Poza tym uwzględnił kryterium rodzaju finansowania, pozwalające na wydzielenie turystyki socjalnej oraz kredytowanej lub finansowanej przedpłatami. Nieco to dublującym było uwzględnienie - jak to nazwał - "aspektu socjologicznego" różnicującego turystykę na luksusową ekskluzywną tradycyjną i socjalną. Najmniej przekonywającym pozostaje kryterium „zachowania się w podróży”, z którym autor wiąże podział turystyki na „rozumną" i „oświeconą".

Na gruncie dyscyplin zajmujących się turystyką przyjęto, że najistotniejszym kryterium wydzielenia form turystyki są cele wyjazdu - utożsamiane z motywami. Jak słusznie podkreśla M. MIKA (2008) - turyści w trakcie podróży realizują odmienne potrzeby i najczęściej kierują się więcej niż jednym motywem; tę cechę turystyki określa się polimotywacyjnością.

Tabela 1. Motywy uprawiania turystyki według różnych autorów

\begin{tabular}{|l|l|l|l|}
\hline \multicolumn{1}{|c|}{$\begin{array}{c}\text { O. RoGALEWSKI } \\
(1966)\end{array}$} & \multicolumn{1}{|c|}{$\begin{array}{c}\text { K. PRZECŁAWSKI } \\
(1979)\end{array}$} & \multicolumn{1}{|c|}{$\begin{array}{c}\text { J. WARSZYNSKA } \\
(1999)\end{array}$} & \multicolumn{1}{c|}{$\begin{array}{c}\text { B. PISARSKA 2004 } \\
(2006)\end{array}$} \\
\hline Wypoczynkowy & Zdrowotny & Wypoczynkowy & Zdrowotny \\
\hline & Rekreacyjny & & \multicolumn{1}{c|}{ Profilaktyka } \\
\hline & & & Leczenie \\
\hline Zamiłowania+umiejętności & Sportowy & & Kondycja \\
\hline Poznawczy & Poznawczy & Poznawczy & Kontemplacyjny \\
\hline & Kult religijny & Religijny & Rozrywkowy \\
\hline & Rodzinny & & Prestiżowy \\
\hline & Studiowanie & & \\
\hline & Praca twórcza & & Inny, np. służbowy \\
\hline & Udział w konferencji & & $\begin{array}{l}\text { Związany z załatwia- } \\
\text { niem spraw }\end{array}$ \\
\hline & Załatwianie spraw & & \\
\hline
\end{tabular}

Źródło: opracowanie własne. 
W tabeli 1 autorka niniejszej pracy zestawiła wykazy dominujących motywów proponowane przez czterech autorów. Zwolennicy generalizacji do dziś powołują się na zestaw trzech głównych celów podróży określony przez O. Rogalewskiego. Przytoczyli go m.in. J. WARSZYŃSKA, A. JACKOWSKI (1979), S. TOCZEK-WERNER (2005) oraz M. NAPIERAŁA, R. MuszKIETA (2011). Na podstawie trzech zasadniczych celów $\mathrm{O}$. Rogalewski wyodrębnił trzy najbardziej powszechne formy turystyki: wypoczynkowa krajoznawczą oraz specjalistyczną (kwalifikowaną).

K. PRZECŁAWSKI $(1979,1994,1996)$ podkreślił, że turystykę można pojmować wąsko; wtedy wiąże się ona z celami: rekreacyjnym, poznawczym i zdrowotnym. Przy podejściu szerokim bierze się pod uwagę pozostałe wyróżnione przez niego cele ( $\mathrm{w}$ tab. 1 podano je $\mathrm{w}$ innej niż oryginalna kolejności z powodu chęci uwypuklenia podobieństw między czterema wykazami motywów). Na ujęcie kwestii podziału turystyki przez K. Przecławskiego powołali się m.in. W.W. GAWORECKI (1982), Z. KRUCZEK (2002) oraz K. MICHAŁOWSKI, R. ZIÓŁKOWSKI (2002).

Z komentarza M. MIKI (2008) wynika, że J. WARSZYŃSKA (1999a, b) wiązała motywację wypoczynkową (rekreacyjną) z regeneracją sił fizycznych i psychicznych, a więc z dbaniem o zdrowie. Autorka ta, będąc autorytetem nie powieliła dalekiego od doskonałości wykazu sześciu celów podróży z 1995 r. według WTO, który obejmuje 37 - częściowo dublowanych pod względem nazwy - celów szczegółowych (podają je MicHAŁOWSKI, ZIÓŁKOWSKI 2002, Terminologia..., 1995).

Autorka niniejszego opracowania poniżej prezentuje (trochę zmienioną) własną kompleksowa, a zarazem zwartą klasyfikację motywów, którą przygotowała w 2004 r. na potrzeby wykładów z socjologii turystyki na WGiSR UW (PISARSKA 2006).

Motywy uczestnictwa $\mathrm{w}$ rekreacji, $\mathrm{w}$ tym $\mathrm{w}$ turystyce według B. Pisarskiej to:

1) zdrowotne:

a) profilaktyka psychofizyczna (odpoczynek od czegoś, kogoś; wypoczynek aktywny i bierny);

b) leczenie psychofizyczne (rehabilitacja i terapia uzdrowiskowa);

c) podnoszenie sprawności i umiejętności w zakresie określonej formy turystyki kwalifikowanej lub sportu amatorskiego; 
2) poznawcze:

a) poznawanie innego człowieka, grupy ludzi, pewnych społeczności; ich poglądów, stylu życia; odwiedzanie krewnych i znajomych (poszukiwanie autentyzmu);

b) poznawanie miejsc, obiektów i krajobrazów, czyli materialnych tworów natury i kultury (w tym obiektów kultu religijnego);

3) kontemplacyjne (poznawanie siebie i sacrum poprzez piękno natury, rozmyślania, twórczość, modlitwę, samotne lub wspólnotowe pielgrzymowanie, odbywanie rekolekcji - nieraz połączone z pustelnictwem);

4) rozrywkowe (związane z potrzebą szybkiego odreagowania stresów);

c) $\mathrm{w}$ zakresie norm (spotkania towarzyskie, $\mathrm{w}$ tym rodzinne $\mathrm{w}$ miejscach rozrywki);

d) poza normami (łącznie z zakłócaniem spokoju innym; niestety coraz częstsze);

5) prestiżowe (udział w kongresach i konferencjach, wyjazdy na studia oraz do pracy twórczej i społecznej, ale także snobizm, moda);

6) inne (większość wyjazdów służbowych, załatwianie spraw, szukanie pracy, zarabianie na życie, np. handel).

W powyższym zestawie motywów podkreślona została terapeutyczna funkcja rekreacji, w tym turystyki, ze względu na to, że dla ludzi pracy umysłowej czy fizycznej każdy - obojętnie, krótszy czy dłuższy - wypoczynek (w tym na wyjeździe) powinien służyć właśnie utrzymaniu, podreperowaniu lub wzmocnieniu zdrowia. Cel zdrowotny jest pierwszorzędny i warto byłoby, aby specjaliści od rekreacji - $\mathrm{w}$ tym turystyki - upowszechniali takie szerokie jego rozumienie.

Autorka przejrzała ponad 20 podręczników akademickich (w bibliografii oznacza je plusem ujętym $\mathrm{w}$ nawias $-\left(_{+}\right)$- zamieszczonym $\mathrm{w}$ notce przed tytułem książki) zawierających klasyfikacje turystyki. Tylko kilku autorów wnikliwiej rozpatrywało to zagadnienie. Większość powoływała się na klasyfikacje, które nie uwzględniały nadrzędności jednych form nad innymi. Chcąc zrealizować tę zasadę i oprzeć się na podobieństwach w klasyfikacji motywów z tab. 1, autorka proponuje poniżej zamieszczoną klasyfikację turystyki. Przy jej konstruowaniu najwięcej inwencji dostarczyły opracowania: H. BORNE, A. DOLiŃSKIEGO (1988), R. FARACIKA, W. KURKA, M. MiKI, E. PITRUSA, D. PtAsZyCKIEJ-JACKOWSKIEJ (2008), W.W. GAWORECKIEGO (2010), 
W. KolasińSKiej (2005), A. KoWAlcZYKA, M. DeReK (2010), A. KRZYMOWSKIEJ-Kostrowickiej (1995), J. MERSKIEGO, J. WARECKIEJ (2009) i D. ZARĘBY (2000).

Klasyfikacja turystyki proponowana przez B. Pisarską:

\section{Turystyka zdrowotna:}

1) turystyka wypoczynkowa;

2) turystyka lecznicza: uzdrowiskowa, medyczna;

3) kwalifikowana = specjalistyczna = aktywna:

a) piesza (nizinna, górska),

b) rowerowa $=$ kolarska,

c) narciarska (zjazdowa, biegowa, wędrowna),

d) wodna (kajakowa, żeglarska, motorowodna, rafting, nurkowa),

e) wędkarska,

f) łowiecka = myśliwska,

g) konna = jeździecka,

h) motorowa (motocyklowa, samochodowa),

i) ekstremalna (wspinaczkowa, jaskiniowa, balonowa, szybowcowa, moto- i paralotniarska, spadochronowa, survival, przygodowa).

II Turystyka poznawcza $=$ krajoznawcza $=$ edukacyjna:

1) turystyka kulturowa:

a) religijna, $w$ tym pielgrzymkowa = pątnicza

b) etniczna = sentymentalna, $\mathrm{w}$ tym narodowościowa, $\mathrm{np}$. polonijna,

c) historyczna (miejsca historyczne, zabytki urbanistyki, architektury, sztuki),

d) etnograficzna,

e) archeologiczna,

f) kulturalna, w tym festiwalowa, eventowa,

g) rozrywkowa, w tym zabawy,

h) kulinarna, w tym winiarska,

i) lingwistyczna = językowa,

j) inne formy, np. wolonatariuszy;

2) turystyka przyrodnicza:

a) geoturystyka (geologiczna, w tym mineralogiczna),

b) florystyczna (botaniczna),

c) faunistyczna (zoologiczna, w tym ornitologiczna, safari),

d) ekosystemalna (krajobrazowa, np. polarna, pustynna, tropikalna). 


\section{Turystyka związana z aktywnością zawodową:}

1) kongresowa, w tym konferencyjna

2) dyplomatyczna, w tym związana $z$ wydarzeniami politycznymi,

3) biznesowa, w tym korporacyjna,

4) handlowa, w tym targowa,

5) zarobkowa.

Autorka, konstruując tę klasyfikację, miała na celu wyróżnienie możliwie najmniej form głównych - zdecydowanie różniących się od siebie, w obrębie których znalazłyby się formy podrzędne, zgodnie z zasadą logicznego porządkowania zbiorów pojęć. Turystyka, stanowiąc część rekreacji, powinna spełniać wymóg dobrowolnej jej realizacji w czasie wolnym. Już jednak w 1963 r. na forum ONZ zdecydowano, że definicja turysty obejmie również podróżujących w sprawach służbowych, w tym w interesach (WARSZYŃSKA, JACKOWSKI 1979). Zostało to potwierdzone przez WTO (Terminologia... 1995). W związku z czym autorka, poza szerokimi zbiorami form turystyki zdrowotnej i poznawczej, wyróżniła zbiór form związanych z aktywnością zawodowa ponieważ na ogół ich stosunkowo nieliczni reprezentanci:

- wyjeżdżają poza miejsce stałego zamieszkania i zatrudnienia;

- korzystają z obiektów turystycznych: noclegowych, gastronomicznych i towarzyszących,

- zwiedzają zabytki: urbanistyki, architektury, sztuki, techniki lub osiągnięcia współczesności.

Są to argumenty za tym, aby z rekreacji nie wykluczać turystyki ze względu na jej formy związane z celami zawodowymi (chodzi np. o turystykę kongresową czy biznesową).

\section{Zakończenie}

Autorka niniejszej pracy uporządkowała na podstawie przeglądu literatury wykazy kryteriów podziału rekreacji, w tym turystyki oraz zaproponowała własne klasyfikacje zajęć rekreacyjnych, motywów i form turystyki. Mnożenie bytów $\mathrm{w}$ postaci nowych form rekreacji, w tym turystyki, nie ma większego sensu, jeśli nie zadba się o możliwość ich podłączenia do kompleksowych klasyfikacji uwzględniających szerokie grupy zajęć; nawet najbar- 
dziej szczegółowa klasyfikacja nie obejmie wszystkich możliwych form. W XXI w. konieczny jest powrót do uniwersalnej teorii systemów, za pomocą której należy doskonalić podstawy teoretyczne dotyczące m.in. kryteriów i klasyfikacji rekreacji, w tym turystyki.

\section{BIBLIOGRAFIA}

BORNe H., DolińSKI A., 1988, (+) ${ }^{1}$ Organizacja turystyki, Wyd. Szkolne i Pedagogiczne S-ka Akcyjna, Warszawa.

CZERWIŃSKI J., 2006, (+) Turystyka. Wybrane zagadnienia. Skrypt dla studentów, Wyd. Państwowej Wyższej Szkoły Zawodowej w Wałbrzychu.

CZERWińSKI J., 2007, (+) Podstawy turystyki, Państwowa Wyższa Szkoła Zawodowa w Legnicy.

DEMEL M., HuMEN W., 1970, Wprowadzenie do rekreacji fizycznej, Sport i Turystyka, Warszawa.

DOŁOWY A., LEWANDOWSKA A., MEYER B., 2006, (+) Rodzaje ruchu turystycznego i formy jego obstugi - rozdz. 3, [w:] B. Meyer, Obstuga ruchu turystycznego, Wyd. Naukowe PWN, Warszawa.

ĎURIČEK M., OBODYŃSKI K., 2006, (+) Syntetyczne podstawy rekreacji i turystyki, Wyd. Uniwersytetu Rzeszowskiego, Rzeszów.

FARACIK R., KUREK W., MiKA M., Pitrus E., PtASZYCKA-JACKOWSKA D., 2008, (+) Rodzaje i formy turystyki-rozdz. 6, [w:] W. Kurek (red.), Turystyka, PWN, Warszawa.

GAWORECKI W.W., 1982, Ekonomika i organizacja turystyki, PWN, Warszawa.

GAWORECKI W.W., 1994, Turystyka, PWE, Warszawa.

GAWORECKI W.W., 2010, (+) Turystyka, PWE, wyd. VI zmienione, Warszawa.

KAMIŃSKI A., 1972, Czas wolny w perspektywie pięciodniowego tygodnia pracy. Opinie i postulaty ludności miast w Polsce, OBOP i SP, Warszawa.

KAPROWSKI W., 1999, 2004, (+) Geografia turystyczna, Wyższa Szkoła Ekonomiczna, Warszawa.

KOlASIŃSKA W., 2005, Podstawy turystyki. Skrypt, Wyższa Szkoła Hotelarstwa i Turystyki, Częstochowa.

KOWALCZYK A., 2001, Geografia turyzmu, Wyd. Naukowe PWN, Warszawa.

KOWALCZYK A., DEREK M., 2010, (+) Zagospodarowanie turystyczne, Wyd. Naukowe PWN, Warszawa.

KRZYMOWSKA-KOSTROWICKA A., 1995, Turystyka ekologiczna i perspektywy jej rozwoju w Polsce, [w:] A. Kowalczyk (red.), Zmiany w przestrzeni geograficznej w warunkach transformacji społeczno-ekonomicznej (na przykładzie obszarów wiejskich), WGiSR UW, Warszawa.

ŁobożEWICZ T., 1996, (+) Turystyka dzieci i młodzieży szkolnej (Przewodnik do ćwiczeń). Skrypt dla studentów AWF (studia 1\%), Wyd. AWF, Warszawa.

ŁOBOŻEWICZ T., 1997, (+) Propedeutyka turystyki, AWF, Warszawa.

MARCiNKIEWICZ C., 2005, (+) Marketing ustug turystycznych, Sekcja Wydawnicza Wydziału Zarządzania, Politechniki Częstochowskiej.

MERSKI J., WARECKA J., 2009, (+) Turystyka kwalifikowana. Turystyka aktywna, Almamer, Wyższa Szkoła Ekonomiczna, Warszawa.

1 Plusem umieszczonym w nawiasie (+) oznaczono podręczniki akademickie zawierające klasyfikacje turystyki. 
MichAŁOWSKI K., ZIÓŁKOWSKI R., 2002, (+) Zarzq̨dzanie turystykq, „Rozprawy Naukowe” 97, Wyd. Politechniki Białostockiej, Białystok.

MiKA M., 2008, Klasyfikacja ruchu turystycznego - rozdz. 6.1 [w:] W. Kurek (red.), Turystyka, Wyd. Naukowe PWN, Warszawa.

NAPIERAŁA M., MusZKIETA R., 2011, (+) Wstęp do teorii rekreacji, Wyd. Uniwersytetu Kazimierza Wielkiego w Bydgoszczy.

PISARSKA B., 2006, Propozycja klasyfikacji wybranych czynników uczestnictwa w rekreacji na tle literatury przedmiotu, [w:] Z.J. Przychodzeń (red.), Problemy rozwoju turystyki na Wileńszczyźnie, Wotyniu i Podolu, Roczniki Wydziału Nauk Humanistycznych SGGW, VIII, Wyd. WSTiJO i Wyd. SGGW, Warszawa.

PRZECŁAWSKI K., 1973, Turystyka i wychowanie, Nasza Księgarnia, Warszawa.

PRZECŁAWSKI K., 1979, Socjologiczne problemy turystyki, Instytut Wydawniczy CRZZ, Warszawa.

PRZECŁAWSKI K., 1994, Turystyka a świat wspótczesny, Uniwersytet Warszawski, Warszawa.

PRZECŁAWSKI K., 1996, Człowiek a turystyka. Zarys socjologii turystyki, Wyd. Albis, Kraków.

PRZECŁAWSKI K., 2004, (+) Człowiek a turystyka. Zarys socjologii turystyki, Albis, Kraków.

SKÓRZYŃSKI Z., 1961, Między pracq a wypoczynkiem. Czas "zajęty” i czas "wolny” mieszkańców miast w świetle badań empirycznych, IF i S PAN, Warszawa.

SuPREWICZ J., 2005, (+) Socjologia turystyki, Wyd. Akademickie Wyższej Szkoły Społeczno-Przyrodniczej w Lublinie.

Terminologia turystyczna. Zalecenia WTO, 1995, ONZ WTO, Warszawa.

TOCZEK-WERNER S., 2005, (+) Podstawy rekreacji i turystyki, AWF, Wrocław.

WARSZYŃSKA J., JACKOWSKI A., 1979, (+) Podstawy geografii turyzmu, PWN, Warszawa.

WARSZYŃSKA J., 1999a, Geografia turyzmu - zarys problematyki, [w:] R. Winiarski (red.), Nauki o turystyce. Stan aktualny - perspektywy rozwoju, "Studia i Monografie” 7, AWF, Kraków.

WARSZYŃSKA J., 1999b, Główne problemy badawcze geografii turyzmu, „Turyzm” 9(1), Wyd. UŁ, Łódź.

WODEJKO S., 1997, (+) Ekonomiczne zagadnienia turystyki, Prywatna Wyższa Szkoła Handlu, Warszawa.

WOLAŃSKA T., 1997, Leksykon: sport dla wszystkich - rekreacja ruchowa, Wyd. AWF, Warszawa.

ZARĘBA D., 2000, (+) Ekoturystyka. Wyzwania i nadzieje, PWN, Warszawa. 
